\title{
DE LA OCASIÓN A LA ALEGORÍA. RETRATOS, IMÁGENES Y FIESTAS TRAS LA VICTORIA DE VIENA DE 1683
}

Data recepción: 2014/01/29

Data aceptación: 2014/05/15

Contacto autor: folllob@upo.es
Francisco Ollero Lobato

Universidad Pablo de Olavide de Sevilla

\section{RESUMEN}

Este artículo analiza el impacto visual y artístico que la victoria de Viena sobre los turcos en 1683 tuvo en España. Se estudia el modo en que se construyen las imágenes de la ocasión histórica, y la forma en que literatura y fiestas convierten el relato histórico en construcciones alegóricas complejas, de tal modo que se convierta en un discurso para la exaltación de la monarquía y sobre todo, del triunfo de la iglesia.

Palabras clave: Carlos II, Sitio de Viena, Barroco, España, Sevilla

\section{ABSTRACT}

This article analyses the visual and artistic impact that Vienna's defeat of Turkish forces in 1683 had in Spain, and studies the way in which images were constructed from the historical event. It also looks at how literature and public celebrations convert the historical event into elaborate allegorical constructions, using it to create a discourse exalting the monarchy and the triumph of the Catholic Church.

Keywords: Charles II of Spain, the Battle of Vienna, Baroque, Spain, Seville

\section{Las noticias de la victoria}

La victoria sobre los turcos y el levantamiento del sitio de Viena en 1683 se convirtió en una noticia de enorme resonancia en los territorios peninsulares de la monarquía hispánica. En realidad, pocos acontecimientos fueron observados por el público español de las postrimerías del XVII con tanta atención como estas batallas de la guerra contra el imperio otomano. Como indicaría el Duque de Maura sobre la ciudad de Madrid, se seguían los acontecimientos vinculados a aquel conflicto "como si el Danubio distase de la Villa tan pocas leguas como el Tajo"1.

Los sucesos acaecidos en las llanuras de la lejana Europa Central fueron pronto conocidos por el público español. La transcendental victoria en las proximidades de Viena, el 12 de septiembre de 1683, que obligó al levantamiento del cerco por las tropas otomanas y su rápida retirada, llegó a la corte el día 2 de octubre, según indica algún impreso coetáneo².
Sin embargo, en ciudades alejadas de la corte, como Granada, tendrían que pasar unos días más para que fuera conocido el acontecimiento. Sebastián Antonio de Gadea y Oviedo, relator de los festejos en esa ciudad con motivo de la derrota del turco, explicaba que sería el lunes 4 de octubre cuando empezaría el rumor de la victoria, pero que no se daría como completamente cierta hasta una semana más tarde ${ }^{3}$.

En cualquier caso, ante tamaña noticia, la información sobre la victoria y la campaña posterior bullía con rapidez mediante fuentes diversas. La curiosidad de los súbditos sería satisfecha mediante el comentario indirecto de correos que informaban a las instituciones de la administración y de la iglesia, y sobre todo, a través de una multitud de relaciones y papeles que circulaban por todas partes. En Madrid, el afán por las noticias sobre los "sucesos del norte" llevarían a la reedición de la Gazeta, en suspenso desde la desaparición de su principal promotor Juan José 
de Austria, y que volvería a la luz en el mes de noviembre de ese año, con números que aportaban datos sobre las Nuevas ordinarias de lo que ocurría en las llanuras centroeuropeas.

En Sevilla, serán los ejemplares de la Gaceta General impresa por Cristóbal López los que informarán de las novedades de la guerra, en especial desde 1684, y los impresos de Juan Francisco de Blas. Por su parte, el impresor Tomás López de Haro publica un Diario numerado sobre los sucesos bélicos, con la edición de cada ejemplar en una plazo medio de uno cada dos semanas ${ }^{4}$.

Esa avalancha de información dispersa sería recopilada y ordenada por determinados compendios, que saldrían a la luz en los meses posteriores a la victoria de Viena. Así ocurriría en la capital de España con los folletos publicados por el librero Sebastián de Armendariz ${ }^{5}$. Entre ellos destaca el preparado por Francisco Fabro Bremundan, secretario del Consejo de su Majestad y antiguo fundador de la propia Gaceta madrileña. Bremundan tomaría la iniciativa de traducir del italiano un texto que, adornado y ampliado en su traducción al español, se convertiría en un destacado sumario de aquellos sucesos. Precisamente ese documento inicial escrito en toscano recibía el título de Ragguaglio... según el autor porque el anónimo quería "distinguirla con alguna ventaja de las Relaciones y Diarios diversos del mesmo assumpto que corrían por la Europa" ${ }^{\prime}$. El texto sería desarrollado con una segunda parte, con los acontecimientos de los dos años siguientes, y una tercera, publicada tras la conquista de Buda en 1686. Seguirían posteriormente una cuarta y hasta una quinta, impresa ya en 1690. Para 1688, y en la ciudad de Barcelona se publicaría una Ungría restaurada... tras el feliz suceso de su reincorporación al cristianismo, que explicará también con acierto el papel jugado por estas reelaboraciones en la información sobre la campaña de la Santa Liga:

sino que para no moler à los curiosos con tanta variedad de papeles sueltos, y derramados, en que se enteran de los sucesos de los Imperiales contra los Barajaros, el ha compilado como Resumen de tantas noticias esparcidas, que mancomunadas ya en este pequeño volumen, se puedan enterar de la verdad toda, sin el enfado de registrar variedad de gazetas, y sin lo importuno de mendigar à diferentes, las noticias ${ }^{7}$.
Pero no sólo será una literatura protoperiodística la que hará posible la asimilación de la campaña contra el turco. Romances, como los publicados por Antonio Fajardo y Acevedo, o villancicos como los creados por José Pérez de Montero para el convento de la Encarnación de Madrid permitirán el conocimiento de los españoles sobre los aspectos concretos de la geografía, las batallas y sobre todo, los personajes históricos que hicieron posible derribar por fin al temible enemigo de Oriente.

La noticia será muy pronto utilizada como asunto en la creación dramática cortesana. Con el argumento del levantamiento del cerco de la ciudad imperial se representaría solo unos meses después de la liberación de la capital imperial la comedia del Sitio de Viena, que se presentaría con ocasión del cumpleaños de la reina Mariana de Austria el 22 de diciembre de 1683 en el Alcázar real madrileño. Al parecer su compleja puesta en escena posiblemente obligó a que se tuviese que dividir la obra en dos jornadas consecutivas. La representación tendría lugar en el famoso Salón Dorado, y se estructuraba como una comedia de tres jornadas, donde el protagonista destacado era el héroe polaco lan Sobieski. La obra constaba además de loa, dos sainetes y un baile como fin de fiesta. Su éxito llevaría a que fuera nuevamente representada incluso antes del término del año. El texto, firmado por el dramaturgo Pedro de Arce, sería rápidamente publicado en Madrid al año siguiente, mediante la impresión de las dos partes de la comedia, en enero y abril de $1684^{8}$. En 1686 , cuando la reconquista cristiana hiciera capitular a la ciudad de Buda, se llevaría al escenario ante la corte una nueva comedia, esta vez a cargo de Francisco de Bances Cándamo, La restauración de Buda.... Con ocasión de ese suceso, Antonio Fajardo y Acevedo, autor de varios romances exaltativos de las victorias cristianas, escribe también su Marte y Belona en Hungría, donde se trata en una única comedia los acontecimientos históricos del enfrentamiento contra el imperio otomano?.

Estas vías de penetración literaria hacían permeable a la opinión popular el conjunto de los hechos históricos, consiguiendo el tono dramático, la escena y la representación vivida de 
los personajes una mirada sugestiva que complementa la información de los correos y diarios, y de los folletos compilatorios de noticias. Este cumplido conocimiento y reflexión de lo conseguido por las tropas de la Liga Santa frente al turco, se ofrecería de un modo tan amplio y consciente para sus contemporáneos, que difícilmente tiene parangón con la transmisión de la información sobre los sucesos inmediatamente anteriores de la monarquía. En comparación con otras obras teatrales cortesanas que celebraban victorias o acontecimientos festivos para la corona, parece significativo que la obra de Arce se representara con tanta proximidad al evento histórico, tal como señala Carmen Sanz Ayán, lo que indica el grado de inmersión de la sociedad de la Real Villa en los sucesos acaecidos; igualmente señala la autora la forma de "crónica representada" con se concibe su representación, frente a otras comedias de tema histórico como las calderonianas del Sitio de Breda o El Primer Blasón de Austria, aspecto éste que acentúa la fuerza noticiosa de los elementos que conformaban su argumento, y en definitiva el valor del propio suceso en su inmediatez.

Sin duda, a la importancia a escala europea de la victoria sobre el turco en su momento de apogeo se unió la transcendencia que tuvo para la monarquía hispánica un triunfo obtenido en una época de melancolía. La conciencia de pertenecer a un período histórico de declinación, evidente para la corte y divulgada por los arbitristas, tenía un correlato directo en los aconteceres políticos, donde el triunfo en las armas hispanas era escaso. El acontecimiento permitía celebrar, al menos por una vez, los fundamentos tradicionales de la política exterior de la monarquía, a saber, la ya deteriorada y fatigosa alianza familiar con los Austrias alemanes, y la función vigilante del rey español al servicio de la fe católica.

Junto a la exaltación de los valores que justificaban el proceder de la política hispánica en Europa, el acontecimiento tenía características extraordinarias. La victoria global obtenida por una alianza de reyes y naciones cristianas fue conseguida frente a un tradicional enemigo de la monarquía austriaca, aquel en quién confluía el carácter herético de su fe religiosa con la extrañeza de la distancia exótica de la antigua Constantinopla y la Europa más lejana. Ello permitía un distanciamiento eficaz del espectador peninsular, que podía asumir la feliz noticia sin las contingencias de una dura implicación que condujera al escepticismo o a la ambigüedad en su resultado emocional. Se trataba de la ejemplificación exacta y rotunda de un ideal sostenido por la retórica áulica que durante estos años de la declinación se había podido concretar sobre los hechos en muy contadas ocasiones.

La Liga Santa y la contienda austriaca habían quedado lejos de las posibilidades de intervención de la exhausta monarquía del católico Carlos II, agobiado por las estrecheces económicas y la presión ejercida por la Francia de Luis XIV sobre las plazas fronterizas. La participación del león hispano sería de naturaleza económica, implicando las rentas de Milán y Nápoles en el sufragio de la contienda. Sin embargo, del impacto mental de la guerra contra el turco y de su carácter de servicio a la monarquía y cruzada religiosa, nos habla el hecho de que para la campaña posterior, y una vez hechas las paces con Francia, se organizara un cuerpo expedicionario formado por voluntarios y dirigido por el Duque de Béjar; este ejército sería el primero en atacar la fortaleza turca de Buda en la guerra de reconquista del este de Europa tras la victoria de Viena, suceso de armas en el que perdería la vida, junto a otros aristócratas españoles, el propio duque ${ }^{10}$.

\section{La construcción de las imágenes}

En los días posteriores al conocimiento de la ruptura del cerco de la plaza imperial, la población española fue capaz, con gran eficacia, de aprehender la síntesis de las acciones militares, y sobre todo, asimilar las acciones más destacadas de los actores de la victoria. Los nombres del emperador Leopoldo I, del general de las tropas imperiales su cuñado Carlos, Duque de Lorena, del defensor durante dos meses de una cercada Viena Conde Ernesto de Starhemberg, y sobre todo, del rey de Polonia que con su energía consiguió acaudillar el ataque sobre los turcos, Juan III Sobieski, serían exaltados y conocidos por las gentes del país. Junto a ellos, se tendría también extensa información de los personajes del ban- 
do enemigo, como el Sultán turco Mehemet IV el gran visir Kara Mustafá o el caudillo húngaro contrario al emperador y en alianza con la Sublime Puerta, Américo Thokóly.

La plasmación en imágenes que ayudarán a la visualización del repertorio de acontecimientos, lugares y personajes de la batalla apareció como una necesidad vinculada al conocimiento y emociones experimentadas con la victoria. En Madrid, en la salida del monarca Carlos II para la tradicional visita a la virgen de Atocha en agradecimiento por la victoria, sabemos que al pie de la torre de Santa Cruz, y culminando un castillo de fuego, se colocó una figura que "decían ser el rebelde Tekeli" con una cuerda al cuello ${ }^{11}$, manifestándose prontamente el deseo de concretar y plasmar los hechos recién aprehendidos.

Pero en realidad, el conocimiento sobre los caracteres físicos de los héroes y enemigos de la batalla sería fácil de adquirir, habida cuenta del extenso repertorio de retratos de príncipes, reyes y personajes relevantes de toda Europa que circulaban por las librerías y tiendas del continente, en la que ha sido denominada como época más activa y dinámica de la vida de las cortes del Barroco ${ }^{12}$. La actividad áulica que permitía el desarrollo de la imprenta, más extensa aún con las mejoras técnicas de la calcografía, permitían libros de abundante estampación como el de la Historia di Leopoldo Cesare, Continente le cose piú memorabili successe in Europa dal 1656 al 1670 (Fig. 1). Esta obra, preparada por Gualdo Priorato, se publicaría sus primeros tomos en Viena entre 1670 y 1674. Ilustrada por grabadores austríacos apoyados por holandeses, se considera la mayor obra impresa de la propaganda imperial en aquellos años ${ }^{13}$. Conjuntos de estampas como estas eran habituales entre la oferta de imágenes de los libreros peninsulares, como en el caso del proceso barcelonés de 1689 mencionado por Bouza, donde no se interpretaba con decoro la imagen real14.

La producción de imágenes relativa a los héroes de Viena tendrá un hito importante en la ilustración del frontispicio que aparece en la primera parte del Floro historico... publicado en 1684. Allí, Gregorius Fosman ${ }^{15}$ sería autor de un grabado donde se disponen los héroes en un

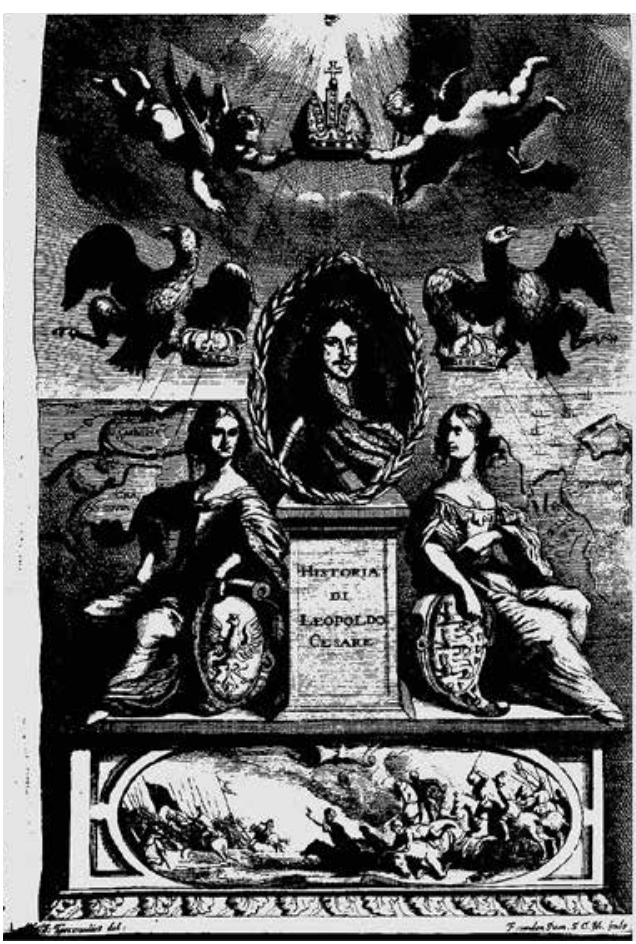

Fig. 1. Frontispicio del tomo I de Historia di Leopoldo Cesare, Continente le cose piú memorabili successe in Europa dal 1656 al 1670, Viena: Gio. Battista Hacque, Stampator Academico, 1670.

conjunto de retratos con orlas, al estilo implantado el emperador, flanqueado por los duques de Sajonia y Baviera, y en la fila de abajo Juan III Sobieski, acompañado por el generalísimo Duque de Lorena y el Conde Starhemberg, defensor de la Viena sitiada (Fig. 2). Este modo de presentar los retratos expuestos se vincula a la actividad de grabadores del Norte de Europa, del que puede ser ejemplo destacado el alegórico de Leopoldo I y Margarita de Austria, estampado en 1669 en Amberes, dibujado por Jean Quellin y grabado por Richard Collin (Fig. 3).

Varios años más tarde y tras la conquista de Buda, saldría a la luz la Hungría restaurada, de Bizozeri, donde se disponen retratos de varios de los héroes de la campaña, con el emperador en las páginas iniciales, el Duque de Lorena, y el rey de Polonia, entre otros personajes y vistas de ciudades $^{16}$. Tal como sucedería en el primer Floro Histórico, y como ha sido señalado por Chacheda, el emperador portará la corona de laurel 


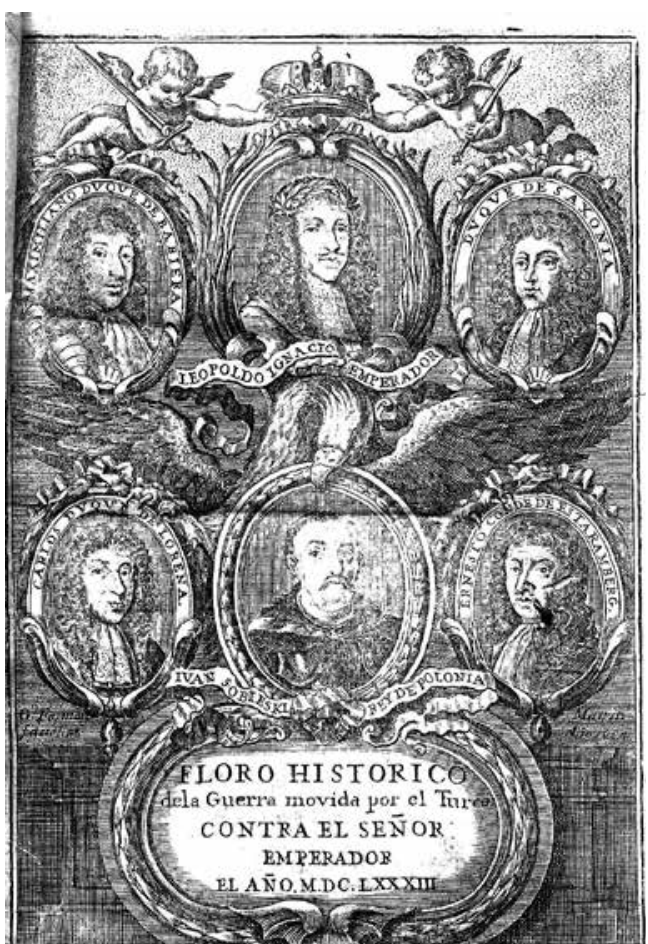

Fig. 2. Frontispicio del Floro histórico de la guerra movida por el sultán de los turcos Mehemet IV contra el augustissimo Leopoldo primero, emperador de romanos, el año M.DC. LXXXIII. Madrid: Imprenta de Bernardo de Villadiego, a expensas de Sebastián de Armendáriz, 1684.

triunfal, convertido más que nunca en un nuevo césar victorioso sobre el turco.

En definitiva, el conocimiento que el público podía tener del rostro, si no verdadero, verosímil, de los gobernantes implicados en la lucha era lo suficientemente amplio como para que los organizadores de una fiesta en Sevilla que conmemoraba la ocasión, al hablar de las figuras que los representaban, pudieran decir que iban "Tan Viuamente imitados/ por retratos sus modelos/ que quién los conoce viuos/ no los ignoró compuestos/"17.

La lectura de impresos, la literatura de villancicos y romances y la caracterización de los personajes en las comedias surgidas tras la victoria permitieron ampliar con realidad o convenciones, la particular visión de los protagonistas. Juan III Sobieski se llevaría el laurel también del favor del público. Su intervención eficaz y pri-

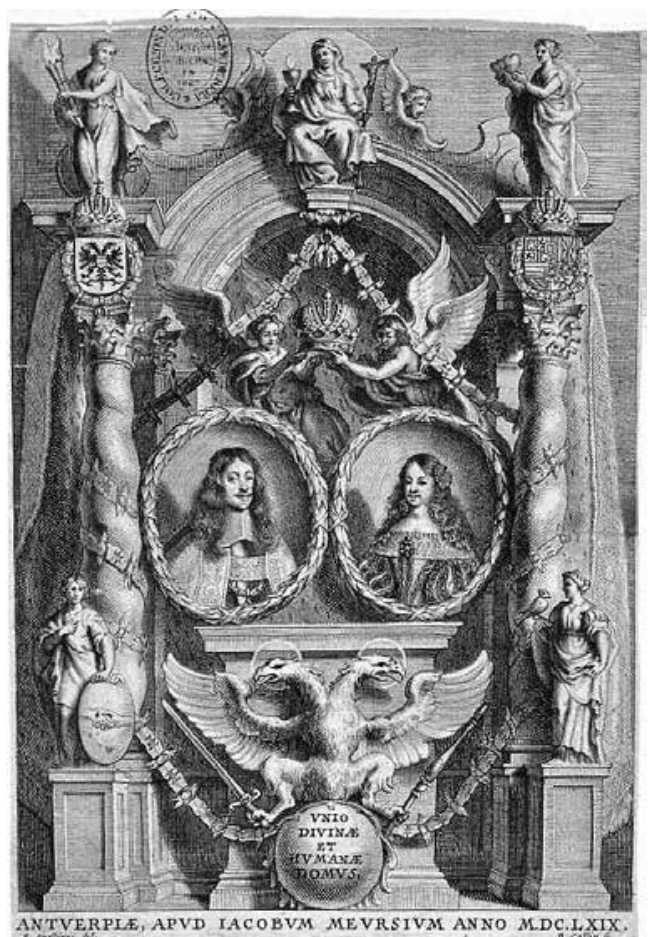

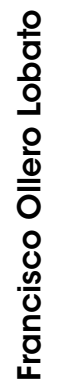

Fig. 3. Retrato alegórico de Leopoldo I y su mujer Margarita de Austria. Amberes, 1669. Diseño de Jean Quellin y grabado por Richard Collin.

mordial en el asalto al turco y su participación personal en la batalla, con la imagen de un crucificado en uno de sus brazos, lo convirtió en uno de los últimos héroes piadosos europeos, según feliz término de Paul Kléber Monod ${ }^{18}$, un "marte católico y fuerte"19, entendido como un enviado de Dios a la manera de un segundo Juan, después del primero, el de Austria, vencedor en Lepanto $^{20}$. Su figura llegaría a protagonizar los papales sobresalientes en el Sitio de Viena... de Arce, desde cuyo palacio se inicia la acción, y se mantendrá posteriormente en Marte y Belona en Hungría, ya en 1686, donde es protagonista. El Duque de Lorena, Carlos, en una posición no tan destacada, se convierte en el actor de las operaciones de los ejércitos imperiales. Calificado como "generoso" por Arce, aparece flanqueado en las noticias por los Duques de Sajonia y Baviera; por su parte, la lealtad domina en el Conde de Starhemberg, el defensor durante dos 
meses de una sitiada Viena, y gobernador de la plaza, quién con tesón defendió las posiciones de la abaluartada ciudad ${ }^{21}$.

El emperador Leonardo I se convertirá en una figura no tan destacada en la acción narrativa, y por supuesto su realidad histórica individual se enmascara en su representación como emperador y abstracta cabeza de la rama austriaca. Aparece como "prudente" y sabio negociador para reunir a los príncipes, aunque desde el distanciamiento, como señala Símini. El perfil del enemigo resulta mucho vasto en sus aspectos fundamentales, y se destacará la ignominia de la total derrota de Mehmed IV, y su fría y ladina perfidia al solicitar a los cristianos la paz a cambio del caudillo húngaro Tekali. Éste, vengativo y de "condición altiva", según la pieza de Arce, irá asumiendo el papel del doble traidor a su señor natural -el emperador-y su condición de bautizado. Su mentor será Kara Mustafá, el visir, empeñado en la guerra para consolidar su gloria y fortuna personal ${ }^{22}$.

\section{La construcción del discurso}

Junto al retrato, unido a las posibilidades de la ocasión, se fue desarrollando un discurso que explicaban los acontecimientos a la luz de los valores suministrados por la fe y el trono. Y esa conformación era, evidentemente para los ojos del XVII, de naturaleza retórica y basada en la sugestión de la metáfora. Poco sabemos del perdido lienzo alegórico del Socorro de Viena, que aún para 1686, en el momento de la conquista de Buda, se encontraba sin concluir en una de las estancias del Alcázar madrileño, y que había realizado el pintor Francisco Rizi ${ }^{23}$. Pero la elaboración alegórica de los acontecimientos ya se acomoda a las necesidades de la puesta en escena del Sitio de Viena... de Arce (Fig. 4), representado en palacio en diciembre del mismo año de 1683. Así, para esa función, el frontis del teatro se había pintado como el Templo de Marte adornado de Trofeos bélicos, y Militares Inflrumentos...", mientras cerraba el espacio a modo de telón una cortina pintada con un jeroglífico, compuesto por el Sol, representado con sus rayos, y la Luna, eclipsada, intermediados ambos astros por el águila imperial, mientras unos muchachos alzaban el mote Solum a Sole ${ }^{24}$.

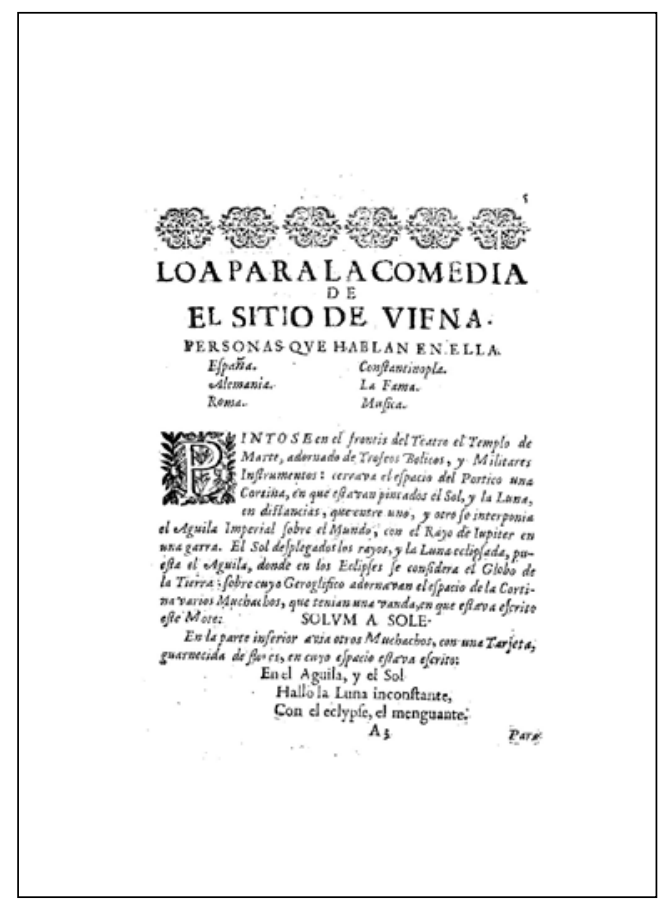

Fig. 4. Loa para la Comedia del Sitio de Viena. Pedro de ARCE: La comedia del Sitio de Viena. Fiesta que se representó a los felices años de la reyna madre nuestra señora Doña Mariana de Austria... Lisboa: Miguel Deslandes, 1684, p. 5.

Se trataba de una representación iconográfica relacionada con la reina durante la monarquía austriaca, en particular a la asociación luna con reina madre -Mariana de Austria, para quien se celebraba la función en su cumpleaños- y el rey Carlos II. Para un reinado donde la luna, habitualmente eclipsada en su estatus, tuvo una función extraordinaria en razón de la minoridad de derecho y de hecho del monarca, ${ }^{25}$ la imagen resultaba perfectamente adecuada para el contexto palaciego donde se desarrolló la representación ${ }^{26}$.

La exaltación de la reina madre se convirtió también, en virtud de la sangre, la procedencia y las preferencias de la reina, en una alabanza hacia la rama familiar centroeuropea, y por ende a la fortaleza de la monarquía austriaca. En la Loa de la obra que tratamos en estas líneas, se produce el diálogo entre las personificadas Alemania y España, para las que la Fama indica "no admira mi cuidado de hallaros juntas, pues sois dos almas unidas". De este modo, la unidad fa- 
miliar, que por asociación al triunfo de los imperiales se convierte también en una victoria de la monarquía de Carlos II, se convertirá en uno de los temas propios de la dedicación literaria al levantamiento del Sitio de Viena.

Esta representación para el ornato de la embocadura y loa de la función de 1683 será el preludio de un proceso de referencias a la familia austriaca que tendrá su momento más destacado en relación con los acontecimientos de la guerra frente al turco tras la conquista de Buda. En los villancicos del Convento de la Encarnación de Madrid, se hará mención a este Sol en este caso divino, que viene del austro, haciendo referencia al versículo bíblico del profeta Habacuc (Deus ab Austro Veniet), de modo que se defina al César emperador como feliz, augusto, fuerte, y finalmente Santo ${ }^{27}$.

Pero incluso desde la propia noticia de la victoria la ocasión se convierte en un suceso directamente unido a la idea ya fijada de la exaltación austriaca y de su papel como protector de la fe. En un sermón sevillano al que haremos referencia posteriormente, compuesto para las fiestas de acción de gracias por la victoria en noviembre de 1683, el orador, en una ejercicio de exaltada elocuencia, llegará a explicar la traición temporal de los húngaros hacia el emperador Leopoldo como una herejía espiritual "no tanto de la Imperial Casa de Austria, y del Señor Emperador su legitimo y natural príncipe, quanto de la católica religión y fe romana, que esta Augusta Casa professa pura, y que a sus heregías y sus vicios hace la más cruda guerra" 28.

De este modo, la victoria en Viena, se convierte en una ocasión para consolidar la visión de la familia austriaca como puntal de la cristiandad, que, mediante a la adquisición de los valores que facilita la representación festiva y la escena, se asumirá como constante temática en algunas de las vivencias rituales populares, como en el caso de las celebraciones de moros y cristianos, en las danzas festivas, o en representaciones teatrales por toda la monarquía hispánica ${ }^{29}$.

La campaña contra el turco de la liga Santa tendrá destacadas implicaciones visuales en el mundo americano. Así, forma parte de los temas de la pintura histórica para los biombos mexicanos, como muestra el vinculado al virrei- nato del Conde Montezuma, José Sarmiento y Valladares, donde se representa el sitio de Viena y en una de sus escenas al Duque de Baviera, y que se fecha hacia $1690^{30}$.

La victoria de 1683 tendrá una importante repercusión en el desarrollo de una iconografía americana, localizada en las tierras del sur andino peruano, la de la monarquía hispánica como defensora de la Eucaristía. Relacionada con el contexto de la imagen del turco como enemigo histórico común, se trata de un tema pictórico utilizado en los templos y en las celebraciones públicas festivas, como la del Corpus, pues así se representa como parte de un altar callejero pintado en un lienzo de la serie de la iglesia de Santa Ana del Cuzco. En este tema se expone la imagen austriaca del monarca joven, que defiende, con espada desenvainada, el dogma central de la Eucaristía, situado en una custodia y elevado sobre un pilar, frente a un número diverso de turcos o musulmanes que tratan de derribarlo. En el plano de gloria de estas representaciones se incluye la Santa Trinidad, acompañada en ocasiones por otras figuras sacras y santos ${ }^{31}$. Al sostenimiento del dogma eucarístico intervienen otros personajes, como frailes angélicos, o la propia santa americana por excelencia, Rosa de Lima, que sustituye íntegramente al soporte, como sucede en un lienzo del Museo de Osma de Lima ${ }^{32}$. Esta construcción iconográfica, desarrollada en los tiempos del obispo de Cuzco Mollinedo y Angulo, perdurará en el siglo XVIII con ligeras variantes con la presencia de los reyes de la casa borbónica, continuadores de la devoción al Santísimo, y a la religión católica en general, que caracterizaba la misión de la monarquía austriaca.

Sin embargo, y por encima de la propaganda áulica de la casa real hispana, asociada o no a la protección de la religión, la ruptura del asedio de Viena propiciará ante todo en España el desarrollo de la imagen barroca de la Roma Triunfante, de la iglesia cristiana que consigue la victoria con la ayuda de Dios y la acción de su principal representante en la tierra, el papa. En la citada comedia del Sitio de Viena, celebrada en 1683, en su Loa, y tras la mencionada alianza entre las personificaciones de España y Alemania, se sucede la representación de las ciudades de Roma y Constantinopla, ambas con un coro, la primera 
de ellas con la imagen de la victoria y con alegre acompañamiento de instrumentos, frente a una apesadumbrada capital de la Sublime Puerta. Recordemos en este sentido que tras la victoria, el papa Inocencio XI proclamará ese día como fiesta universal de la iglesia. En efecto, el papel indudablemente cierto, de la iglesia en la formación de la Santa Liga para la lucha contra los turcos, y la capacidad diplomática desplegada por la curia romana mediante los cardenales Pio y Barberino, plenipotenciarios ante el emperador Leopoldo y Juan Sobieski respectivamente, sería conocido mediante los folletos compilatorios como el Manifiesto general... impreso por Juan F. De Blas en $1683^{33}$. Este conocimiento se unirá en la opinión pública a la comprensión del acontecimiento como un hecho de transcendencia casi escatológica, calificada como: "tan notable la victoria... Que apenas se hallarán semejante en los tiempos pasados" 34 o "el mayor triunfo que ha visto la edad de la Iglesia" ${ }^{35}$. En una época marcada por la lectura del devenir para descubrir la oculta voluntad divina, el conocimiento de la victoria en la corte de Madrid el día 2 de octubre, en la víspera de la fecha de la batalla de Lepanto, no parecía casual, y se interpreta " que hasta en esta circunstancia quiso el Señor se concordasen los tiempos y sucesos"36. De este modo, la reflexión sobre los contenidos del acontecimiento se encaminará, más allá de los hechos concretos, hacia una lectura que exaltase el triunfo de la cristiandad y de la iglesia. Si los personajes de la acción militar como Juan Sobieski son Marte, la intercesión de la virgen la convertía en una "Belona soberana" como se adjetivará a la Virgen de la Antigua de la catedral granadina que había sido sacada en procesión por las calles de la ciudad para auspiciar la victoria sobre el turco ${ }^{37}$.

La traslación de esta construcción mental a la imagen visual operaría entonces con rapidez, gracias a la labor propagandística del triunfo eclesial propugnado desde las instituciones eclesiásticas, los sermones o la reflexión religiosa individual. En el campo de la estampa relacionada con la guerra, la segunda parte del Floro histórico... dedicado a los sucesos de los años 1684 y 1685 , con grabado de portada de Juan Francisco Leonardo (Fig. 5), mostrará ya una disposición de los personajes que atenderá a esta comprensión de las victorias cristianas. El árbol de retratos se hallará adornado por panoplia de armas y insignias, y lo más importante, esta vez a su cabeza se encontrará el papa Inocencio XI, flanqueado más abajo por el emperador y el rey de Polonia ${ }^{38}$, convertido entonces el pontífice en protagonista y principal partícipe de la victoria.

En el campo literario, la idea del triunfo de la cristiandad adquirirá proporciones escatológicas, con el desarrollo de una visión entre el bien y el mal, donde los príncipes y jefes intervinientes en la batalla pasan de considerarse césares o héroes de referencias mitológicas a figuras metafóricas de pasajes del Antiguo o Nuevo Testamento. En este sentido, Juan Sobieski será un heraldo de Dios, que abandonando la comodidad de su reino, viaja para combatir el mal y redimir a Viena, como remedo de la encarnación de Cristo $^{39}$. Para Juan de Gámiz, el orador del Sermón sevillano antes referido, las extraordinarias circunstancias de la victoria sólo pueden ser interpretadas en clave de la voluntad divina, y a modo de conjunción de acontecimientos sobre

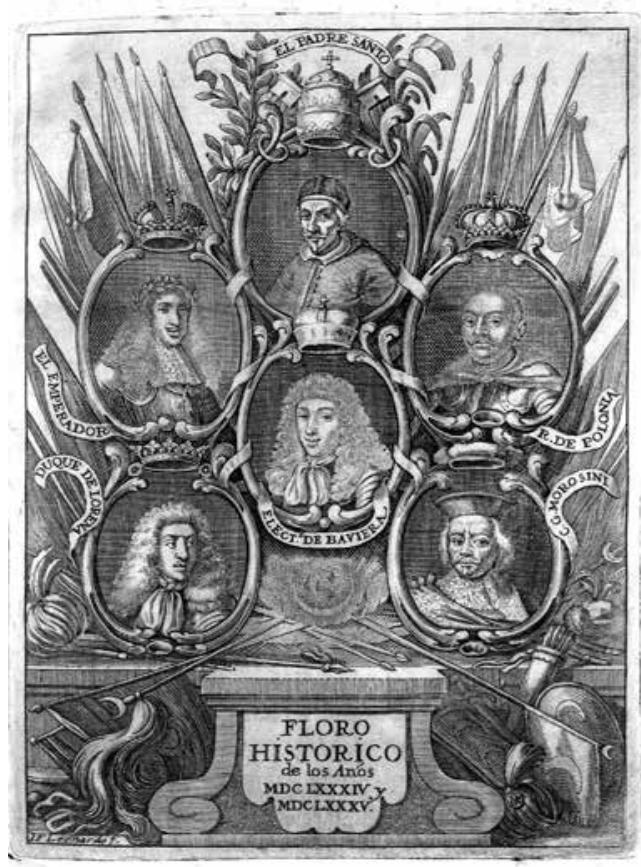

Fig. 5. Frontispicio del Floro histórico de la guerra sagrada contra turcos. Segunda parte, que contiene los sucessos de los años M.DC.LXXXIV y M.DC.LXXXV. Madrid: Imprenta de Antonio Román, a expensas de Sebastián de Armendáriz, 1686. 
los que realiza una metáfora de forzada imagen. Así, la incómoda huida de la familia imperial de Viena ante la próxima llegada del ejército turco es presentada, de manera desafortunada mediante la comparación con la imagen de Belén y el pesebre, donde la Sagrada Familia no hallara asiento. A su vez, se relaciona la convocatoria de los ejércitos aliados con el auxilio de los ángeles del portal, la unión de los generales y príncipes con la de las tribus de Israel, y la penitencia imperial con pies descalzos y portando una cruz, con una nueva imagen de Heraclio en su entrada a Jerusalén ${ }^{40}$.

\section{La fiesta}

El desarrollo de una imagen fundamentalmente eclesial de la victoria de Viena fue preparándose igualmente en las celebraciones festivas organizadas con motivo de la campaña. Carlos II solicitaría el 12 de julio de 1683 rogativa por la liberación del cerco, que en Sevilla llevarían ocho días de plegarias por la mañana y tarde ante la Virgen de la Antigua ${ }^{41}$. En Granada, el prelado solicitaría que toda la ciudad rogase por el cambio de signo de la guerra, y los cabildos eclesiástico y municipal concurrían a misa de rogativa y procesión claustral en la Catedral, mientras se interrumpieron en señal de penitencia otros espectáculos públicos y corridas de toros. El domingo 12 de septiembre la Virgen de la Antigua sería trasladada en procesión por las calles de la ciudad hasta el monasterio de San Jerónimo, en la parte norte de la ciudad, según indica el relator del cortejo, de modo que hasta los impíos "Boreales oriçontes" volase el beneficioso influjo de la imagen ${ }^{42}$ (Fig. 6).

Las celebraciones por la victoria se desarroIlaron por toda Europa, como ocurrió en Roma, Bolonia y Florencia. Ya mencionamos cómo en Madrid, una vez confirmados los hechos por la corte, el monarca Carlos II efectuaría la correspondiente salida de acción de gracias hasta el convento de Nuestra Señora de Atocha para agradecer a la virgen, como era tradición en el siglo de la monarquía española, la buena noticia. Barcelona festejó la buena nueva y los sucesos posteriores con un Te Deum en la catedral el día 12 de diciembre, procesión general, luminarias y un paseo del Virrey y la nobleza por las calles de la ciudad ${ }^{43}$. En Granada la alegría conduciría a tres días de luminarias, en la víspera y en las dos noches siguientes al 24 de octubre, domingo, que se dedicó como fiesta de acción de gracias y procesión claustral de los dos cabildos ante la capilla de la Virgen de la Antigua en agradecimiento por su intercesión. Habría también fiestas en los conventos de trinitarios descalzos dedicados a Nuestra Señora de Gracia, y a Nuestra Señora de las Angustias en su templo parroquial por el Tribunal de la Inquisición, como advocaciones marianas de gran devoción en la ciudad. Más tarde, sería el turno de las fiestas profanas, en forma de corridas de toros en la plaza de Bibarrambla, que se celebrarían los lunes 15 y 22 de noviembre.

En realidad, Gadea y Oviedo, como autor de la Relación que narraría las fiestas de Granada, venía a insistir en el carácter milagroso de la intercesión de la virgen, cuya procesión general coincidió con el día de la victoria de Viena, gloria

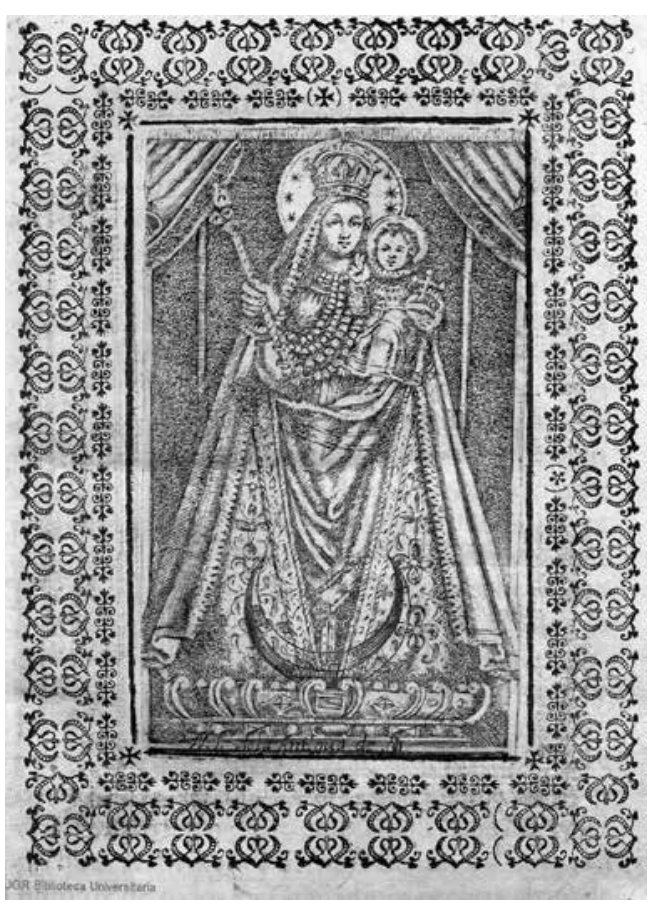

Fig. 6. Virgen de la Antigua de la Catedral de Granada. Grabado calcográfico en Juan PALOMINO (O.S.A), Oración evangélica que predico el M.R.P.M. Fray Juan Palomino ... en la solemne fiesta ... de Maria SSma. ... de Antigua...: Granada: Nicolás Prieto, sacada a luz por los mayordomos de la Hermandad de los escribanos D. Geronimo de Vargas Machuca, y D. Phelipe de Ortega y Robles..., 1711 (1712). 
para Granada "que no alcançó alguna de quantas en toda la Europa han concurrido a tan justa causa" 44 .

La celebración del acontecimiento histórico conllevó un renovado culto hacia las imágenes marianas históricamente relacionadas con las victorias en la lucha contra el Islam. El impulso del papel mediador de las mismas debe relacionarse con el discurso general de importancia del papado y la acción de la iglesia en la cruzada victoriosa contra el turco que conduciría a la victoria de 1683 y los logros posteriores. Si importante fue la acción diplomática del papa y sus representantes ante las naciones europeas para la conformación de la santa alianza contra el turco, también lo fue en el ámbito de la intercesión ante la voluntad divina mediante la oración particular y las rogativas públicas. El papa Inocencio proclamaría el jubileo para favorecer la intercesión de los cristianos ante la divinidad, y tras la victoria, proclamaría el 12 de septiembre como una nueva fiesta universal de la iglesia, con el título del Dulce Nombre de María, asociada por tanto a la acción de gracias por el feliz acontecimiento. De este modo, se reforzaba la interpretación del papel de la virgen como Auxilium christianorum, que, incluso más allá de las gracias invisibles, se hacía también efectiva en los favores materiales, como los propios triunfos bélicos, convencimiento que había llevado en el pasado al nacimiento de la advocación de María como Nuestra Señora de las Victorias, ya como consecuencia de la victoria de 1571 sobre los otomanos en Lepanto ${ }^{45}$.

La devoción a la virgen como Señora de las batallas, a la que se acude en rogativa, y posteriormente en acción de gracias, determina las visitas de Carlos II a Nuestra Señora de Atocha de 1683 y la posterior de 1686 tras la conquista de Buda, según una devoción regia de la casa hispana de los Austrias que tiene su cénit en el siglo XVII. En Sevilla, en el interior de la seo será la Virgen de la Antigua la que recibirá el agradecimiento de las principales instituciones de la ciudad, mientras que vemos cómo la imagen de la misma advocación de la Catedral granadina se convierte en argumento favorable a la propaganda de la ciudad que le da sede, como centro de piedad mariana ${ }^{46}$.
Para el caso de la Relación... de Gadea y Oviedo, se trataba, como indica D`Albis, de la exaltación de la virgen guerrera y milagrosa, y en la composición de la idea de ciudad-mártir, que debe entenderse, a mi parecer, como una introspección de la urbe en términos barrocos, donde la celebración de la fe y la antigüedad de poblamiento, como supuesta Yliberia, "cuios principios encerrados en los misteriosos silencios de tu Antigüedad señalan no pequeños vestigios de tu religión, de tu piedad y de tu gloria"47, se entendían como dos pilares que daban grandeza y lustre a la ciudad.

En Sevilla, como en Granada, el peso de las celebraciones civiles y profanas fue menor que el de las de carácter religioso. Desde el día 7 de noviembre habría tres noches de luminarias en la Giralda y repiques. El día 10 de ese mes se celebraría una misa de Te Deum con la asistencia de los dos cabildos, con procesión dentro de la Catedral y estación ante la Virgen de la Antigua, para terminar ante el altar mayor, del mismo modo en que en otros lugares de España la devoción mariana reconocía a sus advocaciones como fundamental intercesora por la victoria en la batalla ${ }^{48}$. García Bernal ha explicado cómo en el seno del cabildo de la ciudad se asistió a un debate entre los partidarios de realizar unos fastos lujosos, a la altura de la tradición local para con los acontecimientos felices de la monarquía, frente a los jurados y algunos otros regidores, conformes con una contención acorde con una época de decaimiento de la ciudad tras la pérdida del comercio indiano y las secuelas de la epidemia de peste de mediados del siglo ${ }^{49}$. En muchas iglesias e instituciones hubo fiestas religiosas, como la celebrada en la iglesia del Santo Ángel por la Real Audiencia de la ciudad, o las que se llevaría a cabo en el Hospital de la Caridad de la ciudad, en Santa Cruz, en San Isidoro o en San Gil, entre otras. El colegio jesuita de San Hermenegildo organizaría, de acuerdo con una extendida tradición escolar en la ciudad, una máscara jocoseria, con una parte burlesca, en torno a los carros de la Fábula de Vulcano y Marte y la de Baco, y otra de carácter serio, formada por diez cuadrillas, y un carro llamado de Las Parcas, con la fábula Plutón y Proserpina ${ }^{50}$. 
La caracterización última del discurso de la victoria como una exaltación del papado y la iglesia en Sevilla tendrá como centro la festividad organizada por la Hermandad Sacramental del Sagrario de la Catedral. Esta hermandad, asociación devocional para el culto de la Eucaristía, alcanzará por estas fechas un momento cúspide en su desarrollo, tanto en su éxito social como en su culto al sacramento, y entenderá como una de sus obligaciones la celebración del evento vienés. Así lo recoge en su cabildo del día 11 de noviembre, en el contexto de alegría tras las noticias de la victoria en la ciudad, y de las fiestas de acción de gracias de la iglesia catedral, cuando decide realizar también "una fiesta a Dios Nuestro Señor Sacramentado de hazimiento de gracias" 51 . Tras la deliberación de una diputación formada con tal efecto, la hermandad decidiría que para tal fin "se fabricasse un triunfo o nave de la fee, que fuese de fábrica mui hermossa y costossa", elemento central de los fastos que ornamentaran la salida procesional del santísimo por las calles de la ciudad. La decisión de hacer la fiesta servía de explosivo contraste para una ciudad aletargada, y un reto organizativo para la asociación religiosa ${ }^{52}$, que al parecer espero con anhelo disfrutar del espectáculo "que tanto deseaua todo el pueblo de la ciudad"53. Los hermanos se centraron en la organización del festejo, nombrando diputados para los diferentes trabajos requeridos, tales como el aseo del altar, al que se dedicaron dos priostes y hermanos, las banderas y gallardetes, a lo que se dedicaron otros dos, y los fuegos y luminarias, a cargo también de un par de cofrades. Se asignó un mayor número por supuesto -seis personas- a la construcción del triunfo de la fe, y un grupo de ocho para la laboriosa búsqueda de los niños que participasen en la procesión y fueran delante de su carro principal ${ }^{54}$.

Como se pretendía que la fiesta fuera lo antes posible para no distanciarse en el tiempo de la ocasión, se trabajó "de día y de noche" para sus preparativos. La relación en verso de la fiesta recoge en unas rimas los afanes para la construcción del carro, en unas líneas sumamente interesantes para entender los diferentes aspectos necesarios de la celebración y de su ornato perecedero, al cuidado de los diputados de la hermandad:
Unos cuidan de la Iglesia,/otros tratan de su asseo/unos buscan colgaduras/otros primores diversos./Qual riñe con los Pintores/qual da prissa a Carpinteros, Iqual con Colgadores lidia, /quales dan al Triunfo aciertos./Qual no se aparta un instante,/ de estar con los coheteros, /qual se fía en las luminarias/sus mayores lucimientos//(6) Disponer la processión/toman unos por empeño/otros el colgar las calles/con primorosos arreos./Qual luce en los gallardetes, /qual conduce ricos Ternos, /quales buscan con fatiga/galanes infantes bellos,/Qual Geroglificos forma, I y escrive lyricos Metros;/quales van con Legacias/a Tribunales Supremos./Qual con las pomas difundelámbar al espacio aéreo;/ qual en Músicas previene/dar al oído recreos./Ya la prevenciones hechas, lya los Altares compuestos, I llegó el tiempo en que lograsen/su expectación los deseos//55

Elegido el día 28 de noviembre como la fecha de la fiesta ${ }^{56}$, se nombraron diputados para las distintas calles por donde circularía la procesión, y a la vez se desarrolló el protocolo de recepción de otras entidades religiosas que se sumaron a la festividad, como la comunidad de la Veintena, ${ }^{57}$ o la hermandad Sacramental del Salvador, a quién se había dado cuenta antes de las intenciones del recorrido ${ }^{58}$. También se notificó la futura procesión al provisor del arzobispado y visitador del Sagrario, al visitador del vecino Colegio de San Isidoro y a la Casa de Contratación, al arzobispo y al asistente ${ }^{59}$.

La noche de la víspera se dispusieron fuegos artificiales como anuncio de la fiesta, que consistieron en un castillo en las gradas catedralicias, y en el adorno con luminarias de la iglesia del Sagrario, de modo que esta creación efímera apoyara el remate pétreo de antorchas con que se coronaba el antepecho de la fábrica real del edificio $^{60}$. El promontorio ígneo se comparó, como era habitual, con un volcán, el Etna o Mongibelo, aquellos que "De la hermosura y horror unió contrarios extremos/ siendo apacible a la vista/ y dando terror su aspecto". Su incendio, en unas vísperas llenas de señales propicias de astros y cometas, se produjo mediante una hermosa águila que, prendida por las llamas, acababa por hacer arder el promontorio. De este modo, la conformación real de la obra se convierte en un jeroglífico para acentuar la natural "confusión del ingenio" que se supone al efecto de ruido y luces del espectáculo ${ }^{61}$. 
Finalmente, llegó el día de la fiesta preparada con tanto celo. El interior de la iglesia se decoró con damascos y terciopelos, mientras el altar de la iglesia, el tabernáculo exento que se adornara con estatuas de Juan de Arce y que se construyó provisionalmente desde 1662, había quedado compuesto en su cuerpo con bordados sobre fondo blanco, con oro y plata, y con joyas prestadas por el cabildo eclesiástico ${ }^{62}$. En él se colocó a la imagen de la Virgen del Rosario, talla del Sagrario catedralicio cuya advocación se relacionaba con la victoria de Lepanto y cuya festividad se une cercana a la noticia de la victoria (Fig. 7). El racionero de la Catedral y visitador del Sagrario ofició por la mañana la misa con su sermón, con piezas musicales de villancicos y motetes. Para el ornato musical, el cabildo de la hermandad había dispuesto que se trajesen de Cádiz timbales y otros instrumentos, de modo que "en todo sea grande el regocijo"63. Varios motes aparecen en la Relación asociados con el servicio litúrgico de ese día, posiblemente letras cantadas en la celebración.

Al llegar la tarde, se realizó la salida procesional, que por decisión del cabildo de la Herman-

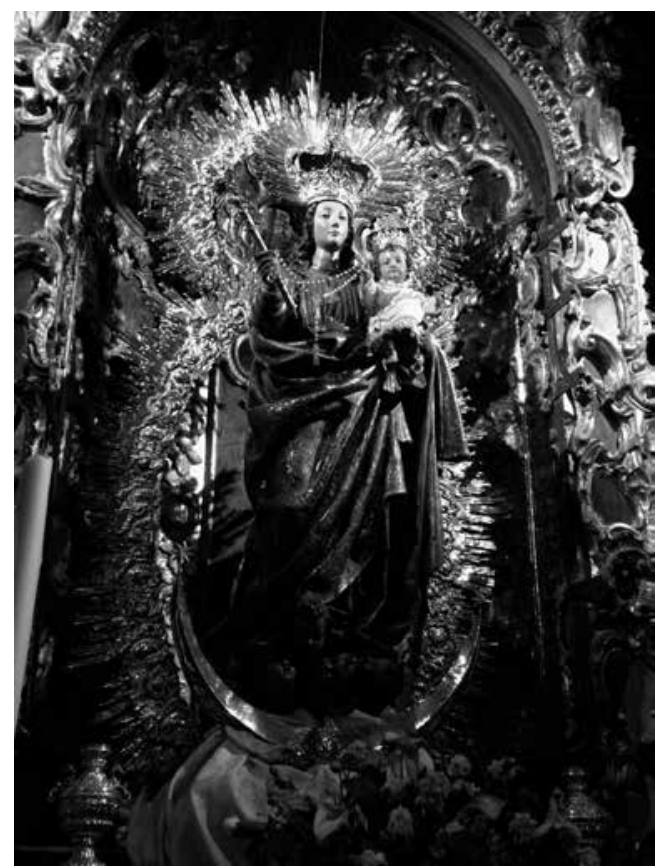

Fig. 7. Virgen del Rosario del Sagrario de la Catedral de Sevilla. Atribuida a Manuel Pereyra (c. 1650). dad Sacramental haría el recorrido de la procesión del Corpus Christi, lo que se conocía como "estación del Corpus", aquella que transcurriría por las calles Gradas, Génova, Plaza de San Francisco, Platería, y Sierpes, para doblar por Cerrajería, y volver por Carpintería, Plaza del Salvador, Culebras, Francos y Placentines hasta regresar a la Catedral. A lo largo del recorrido y previamente a la salida del cortejo, se vieron en lugares distintos danzas al son de pífanos y clarines, y volatines que divertían y servían de reclamo a la presencia del público.

La procesión tendría un orden formado por elementos de raíz profana o alegórica, relacionados también con la principal procesión eucarística de la ciudad, que alternaban con otros aspectos vinculados a la propia hermandad o al clero sevillano. Así, su cabeza estuvo formada por gigantes y tarasca en primer lugar, -disfrazados para la ocasión los primeros como turcos-, trompetas de la ciudad y ministriles. Tras ellos, el orden que "es costumbre" en la hermandad: doce niños hermanos de la cofradía eran seguidos por el guión de la Sacramental. Posteriormente, los hermanos con su cera, el guión "de puntas" y finalmente los señores alcaldes con sus varas "gobernando la cofradía"64. Continuaba el cortejo con un intermedio formado por diversas danzas, de las espadas, danza de cascabel y saraos, con coplas dispuestas para ser cantadas por las voces tiples de los seises.

Seguidamente se dispuso el carro triunfal o de la iglesia, y tras esta alegoría, varios religiosos franciscanos acompañaban la famosa imagen del Niño Jesús del Sagrario, obra de Martínez Montañes. Más tarde seguía la cruz, el clero, con los colegiales de San Isidoro, doce niños vestidos de negro, más sacerdotes con casullas y finalmente, la custodia de plata con el Santísimo Sacramento. El término de la procesión lo formaban la comunidad eclesiástica de la veintena, y el cabildo eclesiástico de la Santa Iglesia Catedral.

Nos detenemos en la descripción del triunfo procesional. Se componía de una amplia nave, pintada en color azul y con adornos de oro "luciendo valiente el arte en dibujos y modelos" 65 . En la popa había pintado "pincel diestro" una vista de la ciudad de Sevilla, y adornaban sus corredores castillos y leones de la monarquía his- 
pana y la giralda y azucenas, símbolo del arzobispado hispalense.

La escena fundamental estaba compuesta por varias figuras en la popa del bajel: un trono dorado, donde se alzaba el papa Inocencio $\mathrm{XI}$, sujeto por cuatro personajes, cada uno de los protagonistas de la victoria: el emperador Leopoldo, el Rey de Polonia Juan Sobieski, su hijo el Príncipe Jaime Luis, y el Duque de Lorena, vestidos con corazas. Junto a ellos, en un puesto inferior, el Conde de Starhemberg, defensor de la plaza imperial. A su lado, se dispuso una dama rematada en su cabeza con una torre, que de esta forma personificaba la ciudad de Viena, con cadenas y grillos quebrados. A los pies del papa, vestido de cortesano y de rodillas, se encontraba la representación de Carlos II, recibiendo el jubileo extraordinario papal dictado en fecha anterior a la victoria frente al turco.

Delante del castillo de popa se hallaba una amplia panoplia de armas y estandartes, con enemigos muertos. El castillo de proa tenía la figura de dos turcos prisioneros, y el jeroglífico del águila sobre la media luna, triunfo austríaco sobre los otomanos. Sobre esa media luna se situó la Fama, con un estandarte del clarín del que pendía el dibujo del ancla de San Clemente, por la primera parroquia de la ciudad, y del Sacramento por la hermandad. Más a proa completaba la nave un león, con argolla dorada del que partían los cabos que simulaban tirar, derrotados, niños vestidos a la turca.

La conformación de las alegorías sobre carros recuerda el recurso propio del auto sacramental, como en los carros de la representación del jubileo en Madrid según texto de Calderón, de la década de los cincuenta, además de las representaciones de El segundo blasón de Austria y El tesoro escondido, de 1679. En Sevilla, este tipo de representación de carros para entremeses y comedias era habitual en la jornada y la procesión del Corpus por la ciudad. El carro como expositor de la alegoría, es decir la unidad de la parada triunfal clásica con la representación de los principios y dogmas religiosos, será ya tratado por Rubens en su Triunfos de la Eucaristía.... Obras ampliamente difundidas en Andalucía mediante los grabados de Nicolas Lawers y Schelte a Bolswert ${ }^{66}$
Pero nos parece especialmente complejo e interesante el conjunto de referencias culturales que vuelan sobre la elección del tema de la nave de San Pedro o de la iglesia; indudablemente, el proceso de reflexión religiosa que acentúa el valor de lo eclesial en el contexto histórico de la victoria vienesa hace entender su elección como un acierto iconográfico. Su representación se rescata durante el Barroco, siendo divulgado mediante grabados, como el del italiano Filipo Tomasini, que tuvieron un amplio éxito posterior, especialmente en el continente americano ${ }^{67}$. Este Triunfo de la Iglesia parece apropiado también ahora para exaltar el papel del papado en la persona de Inocencio XI como cabeza verdadera de una soberanía espiritual, que se reconoce como única razón de la alianza y fundamental causa de la victoria.

Como indica Calbarro, uno de los éxitos de este tema iconográfico consiste en la sencillez comparativa entre el templo y la imagen del bajel ${ }^{68}$. La nave, reiterada en la fiesta sevillana, era un elemento de sobras conocido, que intervenía a través de las galeras y buques del río, como complemento significativo de lujo, riqueza comercial y fuerza militar de los fastos regios y las entradas reales. En su uso religioso, el barco conformó uno de los emblemas grabados en Torre Farfán como conmemoración de las virtudes del monarca Fernando III en fechas cercanas a la procesión que estudiamos, aludiendo a ser alegoría del rey y la recuperación de la ciudad de Sevilla ${ }^{69}$ (Fig. 8). Su uso en otras fiestas barrocas de la España celebrante está ampliamente acreditado, como los carros con tipología de nave presentes en las fiestas valencianas del $\mathrm{XVII}^{70}$

Pero, junto a la reflexión sobre la imagen, debemos contar también con la oportunidad que brindan las circunstancias. La hermandad Sacramental del Sagrario había construido ya en 1662, para las fiestas de inauguración del templo y celebración de un Breve papal inmaculadista, una gran nave, "de trece metros de largo, cuatro de ancho y cinco y medio de alto", de la que fue autor Pedro de Borja, para portar en ella la imagen de la Inmaculada. Según documentación de archivo, Recio Mir ha señalado que su ornato estaba formado por "unas cortezas que formaban sus roleos rebestidos de plata y azul 


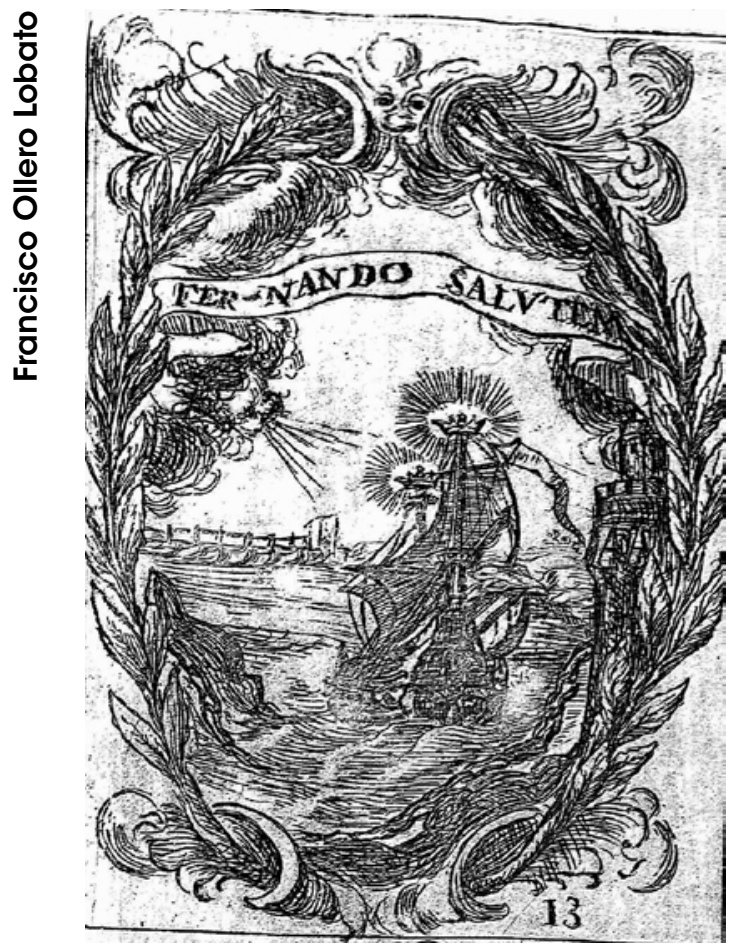

Fig. 8. Jeroglífico grabado por Luisa Morales, en Fernando de la TORRE FARFÁN: Fiestas de la S. Iglesia Metropolitana, y Patriarcal de Sevilla al nuevo culto del señor rey S. Fernando el tercero de Castilla y Leon... Sevilla: Viuda de Nicolás Rodríguez, 1672 , f. 47.

con sus adornos, mascarones y ojas". Es decir, que estaba adornada por los colores que describe el cuerpo de la nave en las fiestas de 1683. Además, para incidir en otro paralelo, aquel carro de 1662 sería igualmente tirado por niños, al modo que se dispone también para los fastos posteriores. De este modo, y pese al deseo de la hermandad por elaborar una fábrica tan "hermosa" como "costosa", uno y otro dato nos obligan a pensar en una perduración, parcial o total, de la estructura construida para aquellas ceremonias con las utilizadas para celebrar la victoria de Viena; la garantía del barroquismo dinámico en la talla de Borja permitía así, dar teatralidad y sentido estético a la superficie de la propia construcción efímera ${ }^{71}$. De este modo, la pervivencia de un modelo formal y unas estructuras heredadas casaron con naturalidad y corrección con la idea de la Nave de San Pedro, y así, adaptación y función, en el uso de los remanentes de otras fiestas por la hermandad, se combinan para conseguir una cuidada y nueva representación alegórica.

Aún las referencias sobre el triunfo permiten una última construcción metafórica en la elocuencia de José de Gámiz, jesuita convidado por la hermandad sacramental, autor del sermón dictado el día 29 de noviembre y publicado como Aclamación panegírica.... Fresco el recuerdo del cortejo, éste se convertirá en un campo de imágenes para su oratoria. Así, establecerá una relación entre el triunfo de la iglesia que pasó por las calles de la ciudad, que es para él a la vez "imagen del sucesso y de la iglesia santa"72 como una nueva carroza de Ezequiel. La cita añade una referencia escatológica acorde con el carácter transcendente con que se analiza la batalla. La referencia no es extraña no sólo en el contexto eclesiástico, sino que se relaciona con una preocupación científica-esotérica sobre las visiones de Ezequiel y el templo que perviven en el barroco. También se acomoda a las imágenes que se establecen en la escena teatral, como ocurre en el teatro de Calderón ${ }^{73}$. Para el clérigo, el triunfo de la iglesia es enigma que se resuelve con la metáfora del trono de Dios en la visión del profeta. La imagen de Dios que presidía aquel carro veterotestamentario es ahora Jesús sacramento, que procesiona con el carro, mientras que, a la luz de los estudios sobre el templo y Ezequiel, y citando a Nicolás de Lira, y a Prado, la imagen del tetramorfo, que respondía a las banderas de los generales del ejército de Israel, ahora se transforman en empresas de la guerra. De este modo, relaciona a Juan Sobieski "generoso" y valiente, con el León; al Duque de Lorena, señalado como "prudente, sabio, cuydadoso, prevenido, experimentado y valeroso" con la imagen del Hombre; "Constante" y "firme" será el Buey, el Conde Starhemberg, defensor de Viena. Finalmente, el emperador Leopoldo se convierte en el águila, "alma" y "ángel"74, que aunque parece que "no assites a la campaña", coordina el movimiento de todos los que intervienen en ella.

Si bien las relaciones escritas relacionadas con esta fiesta no aportan ninguna estampa o diseño de esta procesión y su carro, si identificamos como tal una pintura al óleo sobre lino, custodiada en el Museo de Artes decorativas de 


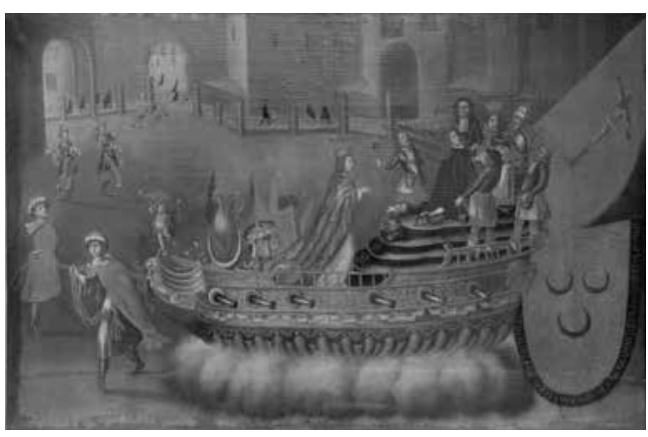

Fig. 9. Carro alegórico de la victoria de Viena de 1683. Museo Nacional de Artes Decorativas. Inventario CE 17909.

Madrid, y en donde se representa una barca alegórica de la victoria sobre los turcos en 1683, en realidad descripción del carro triunfal construido a expensas de la Hermandad Sacramental del Sagrario para las fiestas mencionadas ${ }^{75}$ (Fig. 9). La obra, quizás un boceto para la fiesta, describe la nave del triunfo, que aparece como una estructura agallonada, de dorados y azules, que asemeja la decoración propia de una pieza de orfebrería. Sobre ese ornato, se desplegaba una línea de artillería adornada con tarjas, roleos y mascarones, correspondiendo posiblemente todos estos motivos del casco a la reutilización del que fuera elaborado por Pedro de Borja para la fiesta inmaculadista de 1662. Los personajes y elementos iconográficos sobre su puente y castillos responden con detalle a la descripción escrita de la fiesta señalada, con la precisión de alguno de sus elementos. En la pintura aparece en la proa de la nave la Fama, seguida hacia el interior del buque por el águila bicéfala, con la panoplia formada por el botín conseguido a los turcos. En el puente encontramos a la figura femenina que representa a la Viena liberada, y en el castillo de popa, los principales protagonistas de la batalla, con el rey Carlos II arrodillado ante el papa, tal como describe la relación de la fiesta, levantado este sobre una escalinata y silla y custodiado por el emperador, el rey de Polonia, y los artífices de la victoria. Coronan sus cabezas coronas, y laureles de victoria el joven príncipe de Polonia y el Duque de Lorena, que portan manípulos. Finalmente dos estandartes rematan el final del carro, con un crucificado por encima de las lunas crecientes del imperio otomano. Alrededor del carro aparecen personajes vestidos como turcos, y en el fondo se representa el entorno de la catedral de Sevilla, en concreto el sector de la calle Placentines, donde se observan con claridad las cadenas de las gradas de la seo hispalense, los estribos exteriores del perímetro de las naves y patio de naranjos, así como los restos de lienzos y puerta de origen islámico que separaban la calle de la Puerta de Palos catedralicia.

\section{Conclusiones}

“¿Qué puede explicar la más pulida retórica a los oídos que no sea inferior a lo que están oyendo los ojos?", indicará Gámiz. En realidad, la cuestión es un recurso estilístico, porque precisamente se trataba de desarrollar un conocimiento adquirido por el concepto y la emoción, al avanzar por analogías mediante los recursos de la metáfora, enlazando la imagen y la palabra.

La victoria de Viena se convirtió en una nueva gran ocasión que vieran los siglos. Los elementos psicológicos favorables a la comprensión de un hecho distante pero rotundo, una victoria que por deseada no pudiera ser más benigna, hicieron de la noticia un elemento de enorme interés. El esfuerzo informativo sobre un fenómeno externo a los límites de la monarquía hispánica no tenía muchos precedentes en nuestro país. Además, la idea de cristiandad y el protagonismo reconocido en personajes extranjeros en las fronteras del Norte ofrecía sin duda, una visión europeísta y global del acontecimiento y sus repercusiones inmediatas. Todo ello, divulgado mediante la abundancia de publicaciones y estampas, y la cercanía de las imágenes de los poderosos, crean la impresión de que observamos un fenómeno realmente moderno.

La evolución de la iconografía relativa a la victoria del cerco de Viena en 1683 pasará de ser un elemento descriptivo para el adorno de la ocasión, soportada por la fuerza embriagadora de la noticia y los retratos que circulaban sobre los héroes de la batalla, hacia una evidente alegorización, fundamentada en la exaltación de la Casa de Austria, pero sobre todo en la comprensión de la victoria como un triunfo de la fe y de la iglesia. En la construcción del discurso tendrá importancia la compilación de las diversas fuentes en impresos, pero sobre todo la literatura de 
la escena y de la fiesta. Antes de que la curiosidad general por los sucesos de la guerra acabe, sin que se prolongue mucho más allá de 1686 tras la conquista de Buda, se había desarrollado ya un relato que devolvía a los principios del trono y el altar la consecución de los éxitos.

La misión última será, por supuesto, demostrar la victoria más profunda de la conversión en una vida de obras y penitencia construyendo un puente que conduzca hacia el mundo sobrenatural, en un contexto donde quizás con mayor fuerza durante todo el Barroco se pretendiera conseguir el entendimiento de los acontecimientos a la luz de la voluntad divina. Precisamente, la victoria se interpreta como un ejemplo de intercesión celeste, que incluso ofrece sus favores ante las cuestiones temporales, por lo que se revitaliza precisamente la idea de la capacidad mediadora de las imágenes, especialmente de las marianas, y el poder de la oración. Tal cuestión explica varias actitudes eclesiales, como la declaración de fiesta universal de la iglesia para el Dulce Nombre de María, o, en un nivel más local, las rogativas públicas a la Reina de las Batallas, representadas en la Virgen de Atocha, de la Antigua de Granada, o del Rosario del Sagrario sevillano, entre otras. La ocasión militar también se convierte por tanto en argumento catequético, en una demostración del poder de la oración y la intercesión de la Virgen para solicitar un favor visible, pero que es en definitiva en signo o camino hacia la victoria espiritual de un alma nueva. Así, a través del juego de significados de la alegoría, o de la creencia en la mediación de las imágenes sacras, se devolverá a la sociedad del Barroco la complacencia en valores inconmensurables y ahistóricos, en contraste con el carácter inmediato y noticiable con que se apreciara en principio la ocasión de la victoria.

\section{NOTAS}

1 Gabriel Gamazo Maura, Villa y Reinado de Carlos II, Tomo II, p. 182, citado por Carmen Sanz Ayán, "El ocaso del imperio otomano en Europa" en Gonzalo Anes Álvarez de Castrillón (Coord.), Europa y el Islam. Madrid, Real Academia de la Historia, pp. 415488, concretamente p. 433 y nota 20.

2 Salida en público, a cavallo, del Rey nuestro Señor Don Carlos Segundo, que Dios guarde, a dar gracias al Real Convento de Nuestra Señora de Atocha el Lunes 8 de Noviembre de 1683 por la Gran Vitoria conseguida del Imperio, y Polonia contra el Turco... Luis Antonio de Belmar y Valdivia, citado y transcrito parcialmente por María Cristina Sánchez Alonso, Impresos de Los Siglos XVI y XVII de temática madrileña. Madrid, CSIC, 1981, 722

${ }^{3}$ Sebastián Antonio de Gadea y Oviedo, Noticia sagrada, historial, y politica, de las demostraciones que se han hecho, y celebrado con ocasion del sitio de Viena, victorias, y demas facciones de las armas cesareas, y catholicas, en la muy nombrada, y gran ciudad de Granada, Granada: 1683?, 6v. En Barcelona, la victoria sería confirmada el
20 de octubre, Narciso Feliú de la Peña y Farell: Anales de Cataluña: y epilogo breve de los progressos, y famosos hechos de la nación catalana... BarceIona, Juan Pablo Martí, 1709, f. 381. Véase Rubén González Cuerva, "La última cruzada: España en la guerra de la Liga Santa (1683-1699)" en Porfirio Sanz Camañes (Ed.) Tiempos de cambios. Guerra, diplomacia y política internacional de la Monarquía Hispánica (1648-1700), Madrid, Editorial Actas, 2012, pp. 221-248.

${ }^{4}$ Impresos sevillanos destacados son: Cristóbal López, Relación verdadera y noticias generales venidas con el correo de Flandes en $1^{\circ}$ de enero de 1684 : dase quenta de la guerra que ha publicado el moscouita contra el Turco, y de cómo quiso degollar al Embaxador de Moscouia, con otros sucesos particulares de la Europa : Confirmase assimismo la rebelión contra el turco de las prouincias de Albania, Valachia y Moldauia, y se auisa de la liga que ha hecho la Republica de Venecia con los señores Emperador y Rey de Polonia, â instancia de su Santidad, para la defensa de la Iglesia. Sevilla, a costa de Christoual Lopez, 1684; Continuación historica del estado, sucessos, y progressos de la Liga Sagrada contra Turcos: Dase cuenta de las plazas que las Armas Cesareas han ganado a la Barbara Nacion, y como el Gran Turco haze grandes instancias por la paz con el Cesar, ofreciendo sacrificar à su amigo Tekelí. Seuilla, Christoual Lopez,1684; Juan Francisco de Blas, Relación verdadera, y breue co[m]pendio de todo los sucedido en Alemania, sacado de lo que el señor emperador à escrito à su Magestad Catolica, que llegô a la corte, sabado 23 de octubre de 1683 : refierese todo todo lo que se le à quitado a el Turco, y el aprieto en q[ue] se halla el Gran Visir, co[n]pocos [sic.] de los suyos, sacado por carta q[ue] traxo vn estraordinario, que llegô a esta ciudad sábado 30 de dicho mes. Sevilla, Iuan Francisco de Blas, 1683; Verdadera relación en que se refiere por menor todo lo sucedido en la derrota del exercito Octomano, con dos cartas del señor Rey de Polonia, para su Santidad, y República Veneciana, SeviIla, luan Francisco de Blas, 1683.

${ }^{5}$ Descripción de las plazas de ambas Ungrias, y la Croacia, conquistadas por las armas cesareas desde el año 1683 hasta todo el de 86 ... Madrid, Sebastián de Armendáriz, librero ... en 
la imprenta de Antonio Román, 1686?; Noticias singulares de algunas cosas sucedidas en la ciudad de Constantinopla después de derrotado su exército sobre Viena el año passado de 1683... publicadas el sabado a 2 de diciembre de 1684, Madrid, Sebastian de Armendáriz, 1684.

${ }^{6}$ Francisco Fabro Bremundan, Floro histórico de la guerra movida por el sultan de los turcos Mehemet IV. contra el augustissimo Leopoldo primero, emperador de romanos, \&c., el año M.DC. LXXXIII : Traducido de italiano en casteIlano, y añadido de los sucessos posteriores a la liberacion de Viena. Madrid, imprenta de Bernardo de Villa-Diego, a costa de Sebastian de Armendariz, 1684, Preliminares de la obra. Una de esas noticias, Viena sitiada y socorrida, 1683, comentada por José Luis Martínez Dueñas, "El asedio de Viena de 1683", Chronica Nova, 33, 2007, pp. 371-380.

7 Preliminares de la traducción italiana de Simpliciano Bizozeri (Bizzozero), Ungria Restaurada compendiosa noticia de dos tiempos: del Passado baxo el Jugo de la Tirania Othomana, del Presente baxo el dominio Catholico de Leopoldo II de Austria. Felices sucessos de sus Armas Cesareas, en el Reyno de Croacia, y Principado de Transilvana, Barcelona, Martin Gelabert, 1688. Citado por Rosa Margarita Chacheda Barreiro, La portada del libro en la España de los Austrias menores. Un estudio iconográfico, Tesis Doctoral de la Universidad de Santiago, Departamento de Historia del Arte. 2006.

${ }^{8}$ Carmen Sanz Ayán, Pedagogía de reyes: El teatro palaciego en el reinado de Carlos II, Madrid, Real Academia de la Historia, 2006, especialmente, pp. 123-128; María Luisa Lobato, "Miradas de mujer. María Luisa de Orleans, esposa de Carlos II, vista por la marquesa de Villars (1679-1689)" en Judith Farré Vidal (Ed.) Teatro y poder en la época de Carlos II. Fiestas en torno a reyes y virreyes, Madrid, Iberoamericana, 2007, pp. 13-44.

9 Recoge una bibliografía Diego Simini (Ed.), Antonio Fajardo y Acevedo. Marte y Belona en Hungría. Lucca, Mauro Baroni, editore; también J. Enrique Duarte, "Fuentes y representación de "La restauración de Buda", comedia bélica de Banes Candamo" en Felipe B. Pedraza Jiménez, Rafael González Cañal, Elena E. Marcello (Coord.) Guerra y paz en la comedia española. Actas de las XXIX Jornadas de Teatro Clásico de Almagro. Universidad de Castilla-La Mancha, 2007, pp. 259-274.

10 Gamazo Maura, Villa y Reinado... Op. Cit.

${ }^{11}$ María Cristina Sánchez Alonso, Impresos de Los Siglos XVI y XVII..., p. 450. Salida en público a caballo... Lucas Antonio de Belmar y Valdivia, 1683. Lunes, 8 octubre.

${ }^{12} \mathrm{~F}$ Checa Cremades, "Del gusto de las naciones" en (F. Checa, Comisario), Cortes del Barroco. De Bernini y Velázquez a Lucas Giordano. SEACEX, Patrimonio Nacional, 2003, p. 17-34.

${ }^{13}$ Friedrich Polleross, "Entre "majestas" y "modestas": sobre la representación del emperador Leopoldo I" en Cortes del Barroco..., pp. 151-160

${ }^{14}$ Fernando Bouza, "Por no usarse. Sobre usos, circulación y mercado de imágenes en la Alta Edad Moderna" en Joan Lluis Palos y Diana Carrió-Invernizi, La Historia imaginada. Construcciones visuales del pasado en la Edad Moderna, Madrid, Centro de Estudios de Europa Hispánica, 2008, pp. 41-64.

15 Gregorius Fosman graba láminas de Tierra Santa (plano Corographia Terrae Santae) en la Descriptio lerusalem en tiempos de Jesus, en El devoto peregrino. Viaje a Tierra Santa, de Fray Antonio del Castillo, en 1705. También es el autor del retrato de la reina María Luisa de Orleans en Noticias historiales de la enfermedad, muerte y exequias de la esclarecida Reina de España doña María Luisa de Orleans, Madrid, Francisco Sanz, 1690, entre otras obras (Juan Carrete, Estrella de Diego, Jesusa Vega, Catálogo del Gabinete de Estampas del Museo Municipal de Madrid.. Estampas Españolas Grabados (15501820), Volumen segundo. Madrid, Ayuntamiento, 1985, X.

${ }^{16}$ Ungria Restaurada... Op.Cit.

17 Alonso Martín Braones, Lyrica relación de la fiesta que la llustrissima Hermandad ... del Samtissimo Sacramento en el Templo del señor San Clemente, Sagrario de la Iglesia Catedral ... hizo en acción de gracias de la célebre victoria con que favoreció Dios nuestro Señor las Armas del señor Emperador, Sevilla: Juan Francisco de Blas, 1683, f. 33

18 Referido tanto al rey polaco como a Carlos XI de Suecia y Guillermo de Orange, en El poder de los Reyes. Monarquía y Religión en Europa. 15891715, Madrid, Alianza, 2001.

${ }_{19}$ Pedro de Arce, La comedia del Sitio de Viena. Fiesta que se representó a los felices años de la reyna madre nuestra señora Doña Mariana de Austria... Lisboa, Miguel Deslandes, 1684, f. 12.

20 Sebastián Antonio de Gadea y Oviedo, Noticia sagrada..., f. $8 \mathrm{v}$

21 Verdadera relación... Sevilla, Juan Francisco de Blas, 1683

${ }^{22}$ Así se le representa en el primer Floro Histórico..., f. 4

${ }^{23}$ En el cuarto bajo que cae a la Priora había un cuadro de cinco varas de ancho y más de tres de alto de Francisco Rizi "por acauar", del "Sitio y socorro de Viena". Estaba desmontada. Yves Bottineau," L'Alcázar de Madrid et l'inventaire de 1686. Aspects de la cour d'Espagne au XVIle siècle (5e et dernier article)", Bulletin Hispanique, 1958, Voluumen 60, Número 60-64, pp. 450-483.

${ }^{24}$ Sitio de Viena..., p. 5 y ss.

${ }^{25}$ Los historiadores deberán distinguir si "Carlos II siempre estuvo en minoridad" decía José J. Rodríguez Benitez, Atocha. Ensayos históricos. Madrid: Imp. Juan López Camacho, 1891. Tomo primero. Cap. VI.

${ }^{26}$ Víctor Mínguez Cornelles, "La metáfora lunar. La imagen de la reina en la emblemática española" Millars: Espai i historia, 16, 1993, pp. 29-46; Los reyes solares. Iconografía astral de la monarquía hispánica, Castellón, Universitat Jaume I, 2001.

27 Alain Bégue, "Teología y política en los villancicos del siglo XVII: el ejemplo de José Pérez de Montero" en Francisco Domínguez Matito, María Luisa Lobato (coords). Memoria de la palabra. Actas del VI Congreso de la Asociación Internacional Siglo de Oro, Madrid, Iberoamericana, 2004, Vol 1, págs. 317-330.

28 Juan de Gámiz, Aclamación panegírica en la solemne celebridad que 
consagró a la Santíssima Trinidad y a Christo sacramentado ... la Cofradía del Santissmo Sacramento ... en acción de gracias por la feliz victoria de las Armas Católicas en Viena de Austria ... Sevilla, Imp. De Juan Francisco de Blas, 1684, f. 12 .

${ }^{29}$ Por ejemplo, en la danza por el sitio de Viena, según un manuscrito de La Llacuna, en Cataluña (Ramón Miró I Baldrich, "El ball de Buda", en Quaderns de El Pregoner d'Urgell, 23, 2010, pp. 29-46)

${ }^{30}$ Elisa Vargas Lugo, "La pintura de enconchados", en Ola Saenz (Coord.) México en el Mundo de las Colecciones de Arte, México, Azabache, 1994, p. 123.

31 Como en el lienzo subastado en Christie's, considerado cuzqueño, y proveniente de una colección particular bonaerense (http://www.christies.com/ lotfinder/paintings/anonymous-carlosii-y-defensa-de-la-5262111-details. aspx; noticia en http://reinadodecarlosii.blogspot.com.es/2009/12/ la-imagen-del-rey-en-indias-i-carlosii_2312.html (Consulta 22/03/2013), o el cuadro análogo de la parroquia de San Pedro de Lima, que reproduce Víctor Mínguez, La invención de Carlos II. Apoteosis simbólica de la casa de Austria, Madrid, Centro de Estudios de Europa Hispánica, 2013, lám. 42.

$32 \mathrm{El}$ lienzo donde aparece la figura de la santa es figura 46 de Ramón Mújica Pinilla, Rosa Limensis: Mística, Politica e Iconografía en Torno a la Patrona de América, México, CENCA, FCE, 2005. Véase sobre la iconografía Ramón Mújica Pinilla, "Apuntes sobre moros y turcos en el imaginario andino virreinal" AHlg, 16, 2007, pp. 169-179; Víctor Mínguez, "Iconografía y religiosidad" en Perú: Indígena y Virreinal, SEACEX, 2005, pp. 218233; "España eucarística y sus reinos: el Santísimo Sacramento como culto y tópico iconográfico de la monarquía", en Juana Gutiérrez Hazas y Jonathan Brown (Coords.), Pintura de los Reinos: identidades compartidas. Territorios del mundo hispánico, siglos XVI-XVII, México, D.F. Fomento Cultural Banamex, 2008, tomo IV, pp. 1099-1168, Víctor Mínguez, La invención de Carlos II... especialmente pp. 101-106.
${ }_{33}$ Manifiesto general que haze su Magestad Cesárea, y el rey de Polonia, y otros diferentes Príncipes, en que declaran las razones que tienen para romper guerra contra el Gran Turco, en que se concluyò entre el Señor Emperadory el Señor Rey de Polonia la alianza, y liga ofensiua, y defensiua contra el Turco. Refiérense los Capítulos della y el juramento que hazen ambas Magestades en manos de su Santidad por medio de los Eminentísimos Señores Cardenales Pio y Barberino, Protectores de ambas Coronas: con otras nouedades dignas de saberse, Sevilla, Juan Francisco de Blas ..., 1683

${ }^{34}$ Verdadera relación..., fol. 1.

${ }^{35}$ Gadea y Oviedo, Noticia sagrada..., f. $7 \mathrm{v}$

${ }^{36}$ Salida en público a caballo...

37 Gadea y Oviedo, Noticia sagrada..., f. 10 r

${ }^{38}$ Su iconografía fue estudiada por Rosa Chacheda, La portada del libro... Op. Cit.

${ }^{39}$ En Alain Bégue, "Teología y política en los villancicos..."

${ }^{40}$ Aclamación panegírica... f. 22 y ss. El sermón de Gámiz fue utilizado también como fuente por Miguel Ángel Nuñez Beltrán, "Predicación e Historia. Los sermones como interpretación de los acontecimientos" en Criticón, 84-85, 2002, pp. 277-293.

${ }^{41}$ Diego Ortiz de Zúñiga, Antonio Espinosa y Cárcel, Anales eclesiásticos y seculares... de la ciudad de Sevilla, 1796, Tomo V, 1683, pp. 378

${ }^{42}$ Gadea y Oviedo, Noticia sagrada..., 3-6v.

${ }^{43}$ Narciso Feliú de la Peña Y Farell, Anales de Cataluña..., f. 381.

44 10r, citado por Cécile D' albis, "Les dessous d' un miracle, Grenade et le second siège de Vienne (1683)" en Francisco Nuñez Roldán (Coord.) Ocio y vida cotidiana en el mundo hispánico moderno. Sevilla, Universidad de SeviIla, 2007, pp. 285-296

${ }^{45}$ Carme López Calderón, "El Dulce Nombre de María. Etimología, Anatomía, Efectos y Plástica de los siglos XVII-XVIII", Norba-Arte, Vol. 32-33, 2012-2013, pp. 63-84.

${ }^{46}$ Francisco Arquero Soria, Visitas Reales al Santuario de Atocha, Madrid,
Ayuntamiento, 1976; Jeffrey Schrader, La Virgen de Atocha: Ios Austrias y las imágenes milagrosas, Madrid, Ayuntamiento, 2006. Sobre las imágenes mediadoras en las catedrales españolas, Germán Ramallo Asensio, "La imagen antigua y legendaria, de aparición o factura milagrosa. Imágenes con vida. Imágenes batalladoras. Su culto en las catedrales españolas durante el Barroco" en Germán Ramallo (Coord.) La catedral guía mental y espiritual de la Europa Barroca Católica, Murcia, Universidad, 2010, pp. 37-102. Sobre la advocación de la Antigua, Felipe Pereda, Las imágenes de la discordia. Política y poética de la imagen sagrada en la España del 400. Madrid, Marcial Pons Historia, 2007.

${ }^{47}$ Noticia sagrada... 12V

48 Ortiz de Zúñiga, Anales... Loc. Cit

${ }^{49}$ Los maestrantes tomaron la decisión de culminar con ejercicios ecuestres la celebración de la victoria. José Jaime García Bernal, "Lo serio y lo burlesco: la máscara barroca como forma de pedagogía popular", Demófilo, 18, 1996, pp. 31-47.

50 Se imprimieron la Oración panegyrica y historial en la más plausible fiesta que consagró al verdadero Dios de los exércitos Trino y Uno la... Hermandad de la Caridad de Sevilla, en acción de gracias por el... triunfo que contra el... poder otomano consiguieron las armas catolicas sobre el cerco de Vienal predicola... Fr. Bartolomé de Carmona... de la Orden... San Gerónimo. Sevilla, por Tomás Lopez de Haro... 1683; Francisco Pardo, Sermón predicado en el religiosíssimo Colegio del Ángel, de la esclarecida familia de Carmelitas Descalços, patronato de la Real Audiencia desta ciudad de Sevilla... en la suntuosa festividad, que el día jueves 11 de noviembre deste año 1683 celebró el real acuerdo de la Real Audiencia de esta ciudad. Sevilla: Juan Antonio Tarazona, 1683?. García Bernal utiliza y cita a Felipe Bezerra y Claros, Descripción de la máscara con que el día tres de diciembre del Apóstol de la India San Francisco Xavier solemnizaron la victoria de las armas católicas los estudiantes del Colegio de dsan Hermenegildo de la Compañía de Jesús de Sevi- 
Ila. Sevilla, Juan Vejarano, 1683. Para la fiesta de la Hermandad Sacramental, la citada Lyrica relación de la fiesta... de Alonso Martín Briones, y la Aclamación panegírica... de Juan de Gámiz. José Simón Díaz, en su Bibliografía regional y local de España: I. Impresos localizados (Siglos XV-XVII), (Madrid, CSIC, 1976, 1524) cataloga una Métrica panegírica descripción a las católicas, magnánimas y festiuas demostraciones que la Muy noble y Deuota Hermandad del Santísimo Sacramento, sita en el templo del Señor San Clemente, Sagrario de la Iglesia Metropolitana y Patriarcal de Seuilla hizo en obsequio de gracias al Todo poderoso Dios por la victoria que las Católicas, Cesáreas y Christianas armas del Señor Emperador, Rey de Polonia y gran Duque de Lorena consiguieron contra la Casa Otomana sobre el cerco de Viena este año de 1683, obra de Joseph de Tallada y Villaseca, publicada en Sevilla por Juan Francisco de Blas, 1684. 7 hojas más 24 páginas. Se encuentra en la Biblioteca Nacional (3/75929).

${ }^{51}$ Archivo de la Hermandad Sacramental del Sagrario de la Catedral de Sevilla. Libro de acuerdos (1683-1703) Fol. 14v. (en adelante, AHS)

52 "Votó se hiciesse una fiesta/ en cuyo glorioso empleo/ de los tiempos las miserias/ desmentiesse tanto arresto/ De tan solo doze días/ en el abreuiado tiempo bien como pólvora dio/ más coartada, más estruendo", en Alonso Martín Braones, Lyrica relación... (f. 4)

${ }^{53}$ AHS. Cabildo del 19 de noviembre, f. $16 \mathrm{~V}$

${ }^{54}$ AHS, Cabildo del 13 de noviembre, $15 \mathrm{v}$.

${ }^{55}$ Lyrica relación... $(5,6)$. Versos reproducidos parcialmente por José Jaime García Bernal, Op. Cit

${ }^{56}$ AHS. Cabildo 14 de noviembre, $16 r-v$

${ }^{57}$ Se ofreció tanto para la misa solemne prevista como la a procesión.
AHS, Cabildo ordinario de 21 de noviembre, $17 \mathrm{v}$

${ }^{58}$ AHS. Cabildo extraordinario 24 noviembre, hermandad que mandaría diputación en cortesía para ofrecer la ayuda al festejo. F. $18 \mathrm{v}$

${ }^{59}$ Cabildos de los días 19 y 21 noviembre, respectivamente. Fols. $16 r$ a $17 \mathrm{v}$.

60 "en todas las gradas como en las almenas del Sagrario" AHS. Cabildo del 25 de noviembre, 19r.

${ }^{61}$ Lyrica Relación... (fols. 7 y 8).

${ }^{62}$ Se trataba de un tabernáculo exento, adornado con estatuas de Juan de Arce, que sería diseñado en 1662 una vez inaugurado el templo, por Sebastián de Ruesta. Cfr. Álvaro Recio Mir, "Aquella segunda fabrica que ha de estar en lo interior de la otra»: los proyectos de tabernáculo para el sagrario de la catedral de Sevilla y su realización efímera en 1662" Archivo Español de Arte, LXXVI, 2003, 301, pp. 55-70.

${ }^{63}$ AHS Cabildo 19 de noviembre, $16 r-v$.

${ }^{64}$ AHS Cabildo del 27 de noviembre. $20 \mathrm{v}$

${ }^{65}$ Lyrica relación...

${ }^{66}$ Benito Navarrete Prieto, La pintura andaluza del siglo XVII y sus fuentes grabadas Madrid, Fundación de Apoyo a la Historia del Arte hispánico, 1998, p. 204

${ }^{67}$ En Santiago Sebastián, Iconografía e iconología del arte novohispano, México: Azabache, 1992. Véase Francisco Montes, "La herejía islámica en el imaginario americano", en Inmaculada Rodríguez y Víctor Mínguez (Eds.), Arte en los confines del imperio. Visiones hispánicas de otros mundos, Castellón, Universitat Jaume I, 2011, pp. 129-148.

${ }^{68}$ Juan Luis Calbarro, "Nauis Ecclesiae". Origen e interpretación de una joya iconográfica de Betancuria, en Tebeto: Anuario del Archivo Histórico
Insular de Fuerteventura, 15, 2002, pp. 291-318, donde señala otras referencias literarias del Barroco relacionadas con la iconografía.

${ }^{69}$ Jeroglífico en el altar efímero del interior catedralicio, Grabado por Luisa Morales. Fernando de la Torre Farfán, Fiestas de la S. Iglesia Metropolitana, y Patriarcal de Sevilla al nuevo culto del señor rey S. Fernando el tercero de Castilla y Leon... Sevilla: Viuda de Nicolás Rodríguez, 1672 , f. 47. Su mote "Bajel de curso tan fiel que dio la salud nadando, llamaríase Fer- Nando", el rey como la nave que rompió las cadenas del río, y liberó la ciudad para Cristo

70 Por ejemplo, en las fiestas inmaculadistas de 1662. Cfr. Pilar Pedraza, Barroco efímero en Valencia, Ayuntamiento, 1982.

71 Cfr. Álvaro Recio Op. Cit., y Teodoro Falcón Márquez, "Procesión con motivo del estreno de la iglesia del Sagrario. Documento pictórico del entorno de la Catedral de Sevilla en 1662", Laboratorio de Arte, 12, 1999, pp. 143-152.

${ }^{72}$ Aclamación panegírica... fol. 2

73 Ignacio Arellano, "Notas sobre la Biblia en los autos de Calderón" en V Simposio Bíblico Español. La Biblia en el Arte y la Literatura. Vol. I, Pamplona, Universidad de Navarra, 1999, 17-52

${ }^{74}$ Aclamación panegírica... 5.

75 http://mnartesdecorativas.mcu. es/acceso_catalogo.html Inventario CE17909 del Museo. La imagen recogida en http://reinadodecarlosii.blogspot. com.es/2013/08/la-ultima-cruzada-deespana-el-sitio-de_7150.html (consulta 20/11/2013) Tal como menciona la ficha del inventario, los personajes de la alegoría se identifican con un texto, como "Viena de Austria", "Gobernador de la Plaça" "Rey de España" "Hijo del Rey de Polonia" "Emperador Leopoldo" "Ynoxencio undésimo" así como el Duque de Lorena y el Rey de Polonia. 